\title{
Temporal patterns of settlement in the temperate reef fish Paralabrax clathratus
}

\author{
Amy M. Findlay*, Larry G. Allen** \\ Department of Biology, California State University, 18111 Nordhoff St., Northridge, California 91311-8303, USA
}

\begin{abstract}
Variation in settlement of kelp bass, Paralabrax clathratus, from the pelagic to benthic environment was monitored daily during the summer 1998 on the leeward side of Santa Catalina Island, California. Settlement collectors were placed underwater on buoy lines at 5 to $7 \mathrm{~m}$ depth to provide a standardized form of spatial and structural refuge for settling larvae. SCUBA divers retrieved and replaced collectors each day for $58 \mathrm{~d}$ and totaled the number of kelp bass settlers found. Settlement of kelp bass occurred nonrandomly around the lunar cycle, suggesting a semi-lunar pattern of settlement just after the new and full moons, with peak settlement occurring approximately $5 \mathrm{~d}$ after the full moon. A high, positive correlation was found between settlement and tidal amplitude, and between settlement and onshore winds. A high negative correlation was found between settlement and sea surface temperature. This indicates a strong relationship between settlement of kelp bass and high amplitude tides, drops in sea surface temperature and strong onshore winds. These results suggest that internal tidal bores were a likely means of onshore transport, because bores produce near-bottom onshore flow and are prevalent during high amplitude or spring tides, but especially, they coincide with abrupt drops in sea surface temperature. Back-calculated spawn dates of successful settlers suggested a semi-lunar pattern of spawning just after the new and full moons, with peak activity occurring near the full moon. Kelp bass that settled at spring tides were significantly younger and smaller than kelp bass that settled at neap tides, thus suggesting that settlement of kelp bass is enhanced and larval durations shortened by oceanographic features such as internal tidal bores. Therefore, behavioral or passive synchronization to the lunar and/or tidal amplitude cycles by adult kelp bass during spawning and by kelp bass larvae during settlement result in predictable peaks in daily settlement.
\end{abstract}

KEY WORDS: Settlement · Tidal bores · Moon phases · Tidal amplitude $\cdot$ Reef fish $\cdot$ Paralabrax

\section{INTRODUCTION}

The majority of marine organisms exhibit a bipartite life cycle with a planktonic larval stage and a demersal juvenile and adult stage. Such populations represent 'open non-equilibrial' systems (Talbot et al. 1978) in which local recruitment is independent of local reproductive success and is dependent, instead, upon reproductive success from other sites (Sale 1991, Caley et al. 1996). Therefore, the dynamics and structure of open

\footnotetext{
*Present address: Community Environmental Council, Watershed Resource Center, 930 Miramonte Dr., Santa Barbara, California 93109-1348, USA

${ }^{* *}$ Corresponding author. E-mail: larry.allen@csun.edu
}

populations can be largely dependent on factors that affect the supply of larvae and the successful replenishment of settlers and subsequent recruits.

We refer to settlement as the immediate transition of competent fish larvae from the pelagic environment to benthic habitats, and recruitment as the addition of individuals to local populations after surviving for some arbitrary period of time after settlement (Levin 1993, Caley et al. 1996). It is important to differentiate between settlers that are recent arrivals from the plankton versus those that have settled less recently. One way to differentiate between the 2 stages and avoid complications, is to record settlement of new arrivals from artificial structures that are suitably isolated from nearby reefs and surveyed daily (Victor 
1991, Kenyon et al. 1999). By collecting settlers from artificial refuges on a daily basis, we attempted to separate the large-scale factors influencing settlement from factors operating on a smaller spatial scale, during or after the settlement event (e.g. habitat selection, conspecifics, competition and post-settlement predation; Schmitt \& Holbrook 1996).

Factors influencing settlement may be physical (e.g. wind stress, currents, tides, lunar phases, temperature), biological (e.g. competition for food, predation, behavior) or, more realistically, a complex combination of both sets of processes (Milicich \& Doherty 1994). Oceanographic features can affect the dispersal and settlement of pelagic propagules through: (1) aggregation due to internal waves or tidally induced fronts (Kingsford \& Choat 1986, Shanks \& Wright 1987); (2) larval retention features such as eddies (Milicich 1994, Vargas et al. 1997); (3) drift with prevailing currents or wind-driven forces (Hutchins \& Pearce 1994, Milicich 1994); (4) concentration or pulsed supply of planktonic food necessary for growth and survival (Zimmerman \& Kremer 1984, Witman et al. 1993, Druce \& Kingsford 1995); (5) shelter (e.g. within aggregated algae) and interactions with predators (e.g. predation; Druce \& Kingsford 1995); and (6) onshore movement (Kingsford \& Choat 1986).

Surface slicks generated by internal waves and internal tidal bores are among the onshore transport mechanisms that have been proposed. Slicks of internal waves may influence temporal and spatial patterns of settlement, larval duration, concentrations of planktonic food and the intensity of interactions with predators (Shanks 1983, Kingsford \& Choat 1986). Internal waves are generated during tides with small amplitude and at times when the water column is stratified by a shallow thermocline (Cairns 1968, Kingsford \& Choat 1986, Shanks 1988), as occurs during the spring and summer in the Southern California Bight (Pineda 1994, 1995). As internal waves progress shoreward, downwelling from the rotary currents can concentrate larvae at the convergent zone in the form of slicks (Shanks 1983, Kingsford \& Choat 1986). Surface slicks may be observed at wind velocities below 6 to $7 \mathrm{~m} \mathrm{~s}^{-1}$ (Kingsford 1990), whereas stronger winds obliterate the slicks that delineate convergence zones (Shanks \& Wright 1987). Any organism that can remain at the surface in the convergence zone by swimming or other behaviors (Shanks 1985) will remain in the slick and be transported onshore. The surface slick hypothesis therefore predicts onshore transport of larvae in the surface layer, around small amplitude tides and during periods of low wind.

Alternatively, internal tidal bores may transport larvae in broken internal waves, which are formed during tides of higher amplitude (Pineda 1991). The largest of these internal waves, generated during spring tides, break and progress shoreward as internal bores, producing nearbottom onshore flow and surface offshore flow (Winant \& Bratkovich 1981). If larvae were using internal tidal bores as a means of shoreward transport, one would expect maximum catches near the bottom where the shoreward flow occurs and around the spring tide when flow is strongest (Shanks 1983). The bores produce turbulence which disrupts and weakens the thermocline by creating advection of subsurface cold water (Cairns 1968). The arrival of internal bores on the reef slope is linked to a semi-diurnal tide and is marked by abrupt drops in surface temperature (up to $5.4^{\circ} \mathrm{C}$ ) that last for 2 to 9 d (Pineda 1991, 1995, Leichter et al. 1996). Another distinguishing characteristic of internal bores is the diurnal or semi-diurnal frequency of the temperature oscillations or drops in bottom temperature (Pineda 1994). The internal bore hypothesis therefore predicts onshore transport of larvae closer to the bottom around high amplitude tides, but most markedly, coinciding with drops in surface and bottom temperature.

Larvae of kelp bass Paralabrax clathratus often dominate larval fish collections taken nearshore in the Southern California Bight during the summer months (July to September) (Walker et al. 1987). Larval kelp bass typically spend 3 to $4 \mathrm{wk}$ in the plankton before moving onshore to suitable settlement habitats (Cordes \& Allen 1997). Spawning occurs from late spring to early fall, peaking during the warm summer months (Collyer \& Young 1953, Quast 1968, Lavenberg et al. 1986, Oda et al. 1993). Back-calculated spawning dates (Cordes \& Allen 1997) have suggested a lunar periodicity centered around the full moon, even though kelp bass may be capable of daily spawning (Oda et al. 1993). Due to the protracted duration of the larval stage, nearly all kelp bass offspring can theoretically disperse far enough away from the parental population to effectively decouple local egg production from the supply of offspring to that local population (Carr 1994). Consequently, physical processes may play a vital role in the onshore movement of planktonic kelp bass to nearshore habitats.

The specific objectives of our study were: (1) to examine temporal patterns in the settlement of kelp bass in order to identify possible periodicity or cycling patterns; (2) to correlate settlement with various physical parameters measured in the field; and (3) to propose a mechanism for the onshore transport of kelp bass larvae.

\section{MATERIALS AND METHODS}

Field collection. All research was conducted at the Wrigley Marine Science Center located within Big Fisherman Cove on Santa Catalina Island $\left(33^{\circ} 27^{\prime} \mathrm{N}\right.$, 


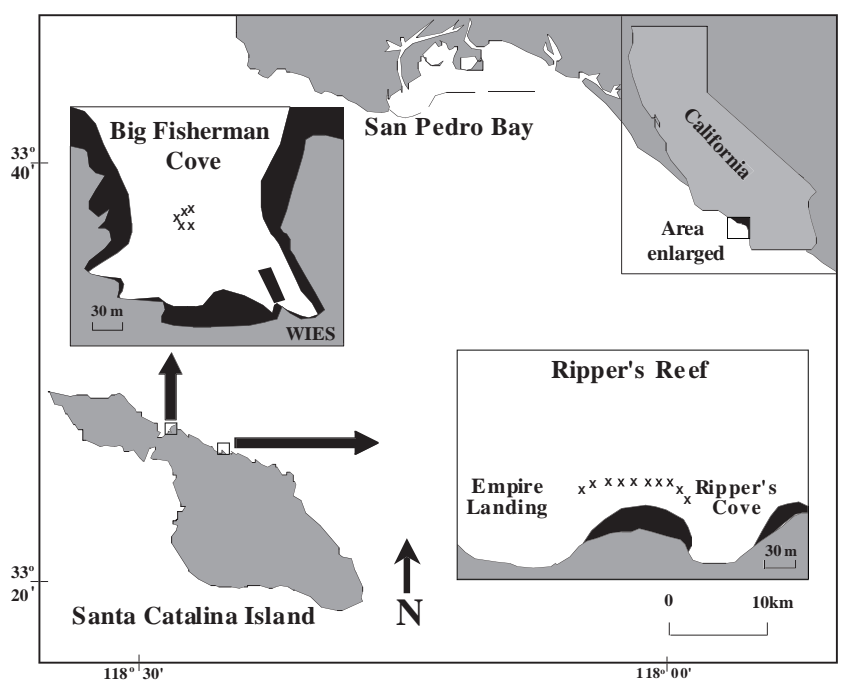

Fig. 1. Map showing the position of Santa Catalina Island relative to the coast of southern California, the location of the Wrigley Institute for Environmental Studies (WIES), the location of the sampling sites and the spatial arrangement of sampling buoy lines. Sampling was conducted at Big Fisherman Cove and Ripper's Reef in 1997 and 1998, respectively. $\mathrm{x}$ : sampling buoy lines

$\left.118^{\circ} 29^{\prime} \mathrm{W}\right), 35 \mathrm{~km}$ offshore of southern California (Fig. 1). Field sampling was conducted from July to September of 1997 and 1998, covering the peak times of settlement for kelp bass at Santa Catalina Island (Carr 1991). Monitoring of settlement was achieved with the use of settlement collectors (cf. Carr 1991), which provide a standardized form of spatial and structural refuge for settling kelp bass.

Settlement collectors were secured to anchored buoyed lines and censused on a daily basis by SCUBA divers. Collectors were retrieved and replaced, early each morning (07:00 to 09:00 h). Shenker et al. (1993) and Thorrold et al. (1994) found that approximately 92 and $97 \%$ of the fishes caught in their study were taken at night, indicating that the majority of their fish taxa settled during the night. Divers carefully removed the collectors from the buoy lines and placed them within fine mesh bags. At the lab, collectors were agitated and rinsed within the bags to remove any fish. Fish were then measured to the nearest $0.01 \mathrm{~mm}$ standard length (SL) and the numbers of kelp bass settlers were pooled into daily totals.

A pilot study was conducted in the summer of 1997 to determine if the settlement of kelp bass differed with depth. Sampling at Big Fisherman Cove (Fig. 1) was conducted over a $52 \mathrm{~d}$ period. Five buoy lines were placed approximately $10 \mathrm{~m}$ apart within Big Fisherman's Cove in approximately $20 \mathrm{~m}$ of water. Each line contained 3 pairs of collectors at 3 depths: surface (0 to $1 \mathrm{~m})$, mid (5 to $7 \mathrm{~m}$ ) and deep (12 to $14 \mathrm{~m}$ ).
Summer 1998. Ripper's Reef (Fig. 1) was established as the primary sampling site during the summer of 1998. Of the many reefs surveyed for recruitment of kelp bass at Santa Catalina Island, Carr (1991) observed consistently high recruitment to this reef. The Big Fisherman's Cove site was abandoned due to the low numbers of kelp bass settlers caught during the summer of 1997 . Ten buoy lines were anchored approximately 10 m off Ripper's Reef, at depths ranging from 8.5 to $13.5 \mathrm{~m}$ and buoy lines were set approximately 20 to $30 \mathrm{~m}$ apart from one another. Two collectors were placed one directly above the other on each buoy line at a depth of 5 to $7 \mathrm{~m}$. Sampling was conducted over a $58 \mathrm{~d}$ period.

Measurements of the physical environment. Temperature loggers were secured at 3 depths ( 0 to 1, 5 to 7 and 10 to $12 \mathrm{~m}$ ) on a buoy line in the middle of the study site, and retrieved weekly and downloaded to a computer. The temperature loggers were set to record in 10 min intervals, which were later averaged over a $24 \mathrm{~h}$ period. An InterOcean Inc. $\mathrm{S} 4^{\odot}$ current meter was secured to the bottom near the base of the middle buoy line $(0.5 \mathrm{~m}$ off the bottom) and was programmed to record current velocity and direction in $10 \mathrm{~min}$ intervals. The readings were recorded as velocity components (north-south and east-west) and averaged over a $24 \mathrm{~h}$ period. Wind velocity and direction was obtained from a NOAA wind profiler located on the hillside at the Wrigley Marine Science Center, recorded as velocity components (north-south and east-west) and averaged over a 24 hour period. Tidal amplitude was recorded as the change (in tidal height) between the highest high and lowest low tides for each sampling period.

Otolith extraction and preparation. In the laboratory, kelp bass sagittal otoliths were removed and mounted medial side down on slides with cyanoacrylate (Superglue) medium. The left sagittae were used for the aging studies; however, where left sagittae were unreadable or broken, right sagittae were used instead. The majority of sagittae from small fish ( $<10 \mathrm{~mm}$ SL) were read easily and required no grinding. However, some sagittae, especially from larger fish (>10 mm SL) required grinding and polishing, which was done on a sagittal plane using 15, 12, 3 and $1 \mu \mathrm{m}$ lapping films (3M) and a special grinding platform devised by Jensen (1990). Lapping films were used in descending order until increment rings were visible from the focus to the outer edge of the otolith.

Otolith daily increments. Only kelp bass from the 1998 study at Ripper's Reef were aged. A total of 94 kelp bass were randomly selected among lunar phases for aging. All otoliths were viewed under immersion oil. The presence of daily growth rings in kelp bass 
otoliths has been validated by Cordes \& Allen (1997). Daily growth rings were defined as 1 hyaline and 1 opaque band and were distinguished from subdaily rings using the criteria set forth by Campana (1984).

Daily growth rings were counted from the central nucleus to the edge of the otolith, on 3 separate occasions, without knowledge of the prior counts. The mean of the counts was taken, unless they differed by more than 3, in which case the otolith was rejected. A correction factor of $2 \mathrm{~d}$ was added to all counts since laboratory reared kelp bass do not produce daily growth rings until Day 3 of life (Cordes \& Allen 1992).

Statistical analysis. Kelp bass collected at Big Fisherman's Cove in 1997 were pooled from all collectors at a given depth into daily totals. This data was non-normal after transformation, therefore, a nonparametric Kruskal-Wallis ANOVA was performed followed by nonparametric Tukey-type multiple comparisons on the number of kelp bass per depth zone (Zar 1984).

Rayleigh tests were used to test whether settlement of kelp bass and estimated spawn dates in 1998 were random around a lunar cycle (Batschelet 1981). The number of settlers per day and spawn dates, were pooled independently into a single lunar cycle (starting with the new moon) and converted into percentage of settlers and spawn dates per lunar day. Where the distribution of settlers/spawn days was non-uniform, circular statistics were used to obtain both the mean lunar settlement and spawn day (mean vector angle) and mean angular deviation (Batschelet 1981). The mean vector of the circular distribution was taken to be the date of peak settlement. In addition, non-uniform cycling patterns were further examined by spectral analysis using a periodogram approach, which identifies cycles within the time series at which most of the variance of the data are concentrated. Highest and widest peaks were interpreted as the dominant periodicity (Chatfield 1980).

Linear regression was used to estimate the ages of all measured kelp bass from 1998 to achieve a more concise back-calculation of spawning dates. A linear regression of the aged kelp bass on their standard lengths was calculated and this equation was applied to all the settlers that were measured to the nearest $0.01 \mathrm{~mm}$ SL. Of the total kelp bass aged, 89 were measured and used to generate the linear equation.

Nonparametric rank correlations were used to test the relationship between settlement of kelp bass at Ripper's Reef in 1998 and the physical parameters measured in the field, each tested independently (Sokal \& Rohlf 1995). Abrupt declines in surface temperature are indicative of internal tidal bores (Pineda 1995). We analyzed sea surface temperature data for evidence of internal bores. Temperature data were detrended to remove the warming over the sampling period (Statistica ${ }^{\mathrm{TM}}$, StatSoft). In all correlation analyses, a Bonferoni adjusted significance level of 0.0125 $\left(\alpha^{\prime \prime}=\alpha / k_{;} \alpha^{\prime \prime}=0.05 / 4\right)$ was used to limit the error from repetitive testing of kelp bass settlement against the 4 physical parameters (Sokal \& Rohlf 1995).

Wind velocity components were compared because settlement of larval fishes has been correlated with strong onshore winds in a variety of studies (Milicich 1994, Thorrold et al. 1994, Kingsford \& Finn 1997). Current velocity components were also compared because currents on the leeward side of Santa Catalina Island traditionally run east-west (Zimmerman \& Kremer 1984).

Newly settled kelp bass collected daily during 1998 were grouped into either new, first quarter, full or third quarter moon phases $( \pm 3 \mathrm{~d})$ and tested for significant differences in length at settlement and age at settlement per moon phase using 1-way ANOVA. No significant difference was found between new and full moons and between first and third quarter moons for both length at settlement and age at settlement. Therefore, the data were collapsed into new and full moons (or spring tides) and first and third quarter moons (or neap tides) and tested again using 1-way ANOVA.

\section{RESULTS}

A total of 273 kelp bass were caught in the daily settlement collectors over the 2 summers of sampling, with a mean length of $9.44 \mathrm{~mm}$ SL $( \pm 0.78 \mathrm{SD})$ and range from 7.94 to $18.47 \mathrm{~mm} \mathrm{SL}$. A total of 42 settlers were collected over a $52 \mathrm{~d}$ period at Big Fisherman Cove during the summer of 1997. The number of daily settlers collected per depth zone differed significantly

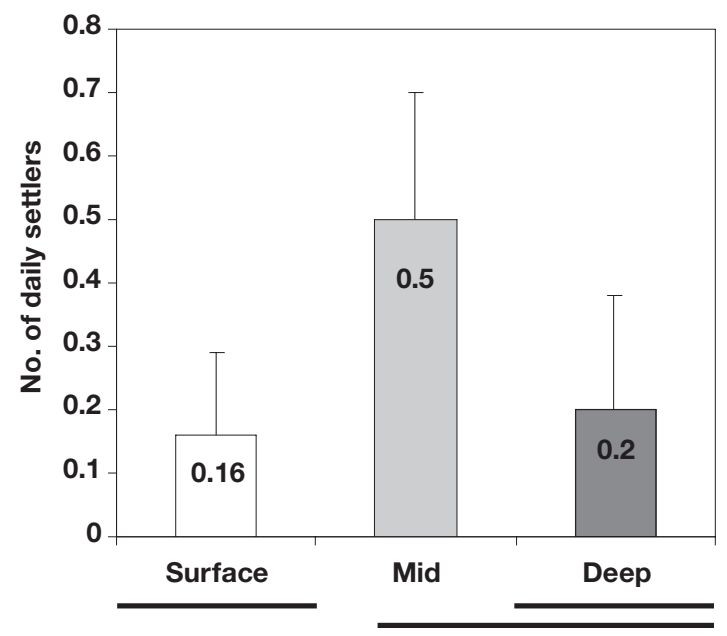

Fig. 2. Paralabrax clathratus. Mean (+SE) daily settlement to 3 depth zones in 1997: surface (0 to $1 \mathrm{~m}$ ), mid (5 to $7 \mathrm{~m}$ ) and deep (12 to $14 \mathrm{~m})$. Underlined depth zones are not significantly different 
(Kruskal-Wallis ANOVA, $H=7.45, \mathrm{df}=149, \mathrm{p}=0.0241$; Fig. 2). Post hoc comparisons revealed that settlement at mid-depth was significantly higher than at the surface $(p=0.039)$. Based on these results, collectors were placed only at mid-depth throughout the sampling in 1998, specifically to maximize the total number caught.

\section{Temporal patterns of kelp bass settlement}

A total of 231 daily settlers of kelp bass were collected over $58 \mathrm{~d}$ at Ripper's Reef in 1998. A plot of daily settlement of kelp bass against the lunar cycle suggested a semi-lunar pattern of settlement, as peaks were found near new and full moons (Fig. 3).

A highly significant Rayleigh $Z$-statistic $(Z=54.9$, $\mathrm{df}=230, \mathrm{p}<0.001)$ determined that settlement was not uniformly distributed around the lunar cycle (Table 1). The mean vector of the circular distribution (Fig. 4) represents the date of peak settlement, which was D $19.7 \pm 4.7$ SD of the lunar cycle, approximately $5 \mathrm{~d}$ after the full moon. Spectral analysis revealed a dominant $14.5 \mathrm{~d}$ cycling period, along with a strong cycling period of $29 \mathrm{~d}$ (Fig. 5).

\section{Environmental correlates with settlement of kelp bass}

A significant positive correlation $(\mathrm{R}=0.37, \mathrm{df}=57, \mathrm{p}=$ 0.004 ) was found between settlement of kelp bass and tidal amplitude (Table 2), suggesting that peaks in settlement occur at or near tides with high amplitudes or spring tides. Spectral analysis of detrended mean daily temperatures revealed a dominant $29 \mathrm{~d}$ cycling period and a subdominant $14.5 \mathrm{~d}$ cycling period (Fig. 6). This coincides with the 2 highest cycling periods in settlement (Fig. 5). Detrended surface temperatures were significantly and negatively, correlated with settlement of kelp bass $(R=-0.37, \mathrm{n}=58, \mathrm{p}=0.004)$, suggesting that peaks in settlement of kelp bass occurred during abrupt declines in surface temperature. A significant correlation was also observed between settlement of kelp bass and

Table 1. Paralabrax clathratus. Rayleigh Z circular statistics for cycling patterns in daily settlement at Ripper's Reef in 1998. Estimated back-calculated spawn dates determined from the length-age regression equation. Z: Rayleigh test statistic; lunar day calculated from the mean vector angle (d); s: mean angular deviation (d)]. ${ }^{* * *} \mathrm{p}<0.001$

\begin{tabular}{|c|c|c|c|c|}
\hline & Z & $\mathrm{n}$ & Lunar day & $\mathrm{s}$ \\
\hline $\begin{array}{l}\text { Daily settlement } \\
(58 \mathrm{~d})\end{array}$ & $54.9^{* * *}$ & 231 & 19.7 & 4.7 \\
\hline $\begin{array}{l}\text { Estimated back- } \\
\text { calculated spawn dates }\end{array}$ & $95.0^{* * *}$ & 187 & 20.5 & 3.5 \\
\hline
\end{tabular}

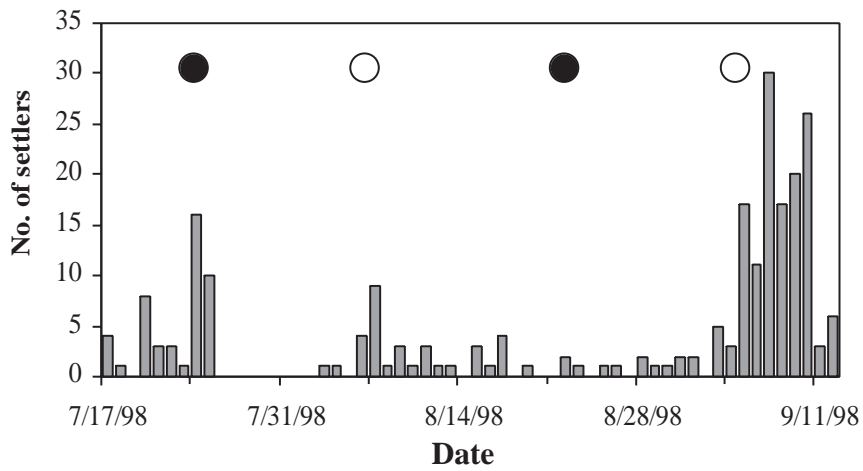

Fig. 3. Paralabrax clathratus. Daily settlement of kelp bass at Ripper's Reef $(n=231)$ over a 58 d period in 1998. Dates given as $\mathrm{mo} / \mathrm{d} / \mathrm{yr}$. $\bullet=$ new moon, $\mathrm{O}=$ full moon

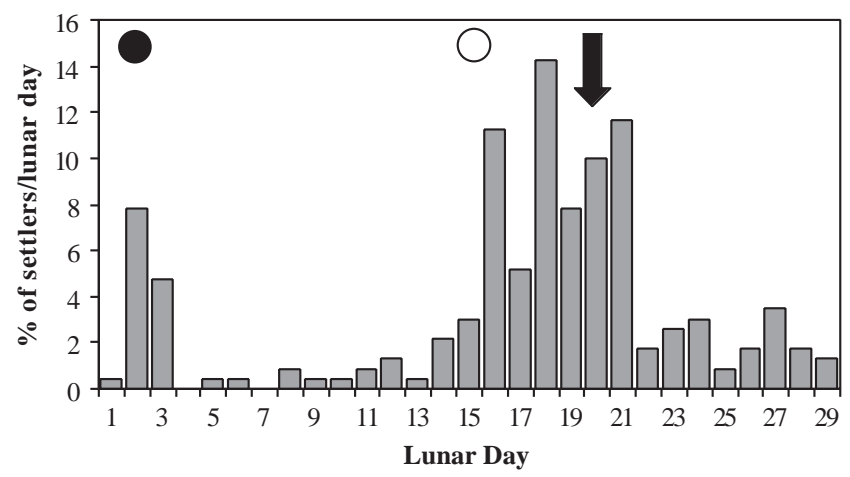

Fig. 4. Paralabrax clathratus. Lunar patterns of daily settlement at Ripper's Reef in 1998 based on Rayleigh statistics. Settlers $(n=231)$ were combined into a single lunar cycle, starting with the new moon and converted into percentage of settlers per lunar day. $\bullet=$ new moon, $O=$ full moon. The downward black arrow indicates the date of peak settlement (Day 19.7, see Table 1)

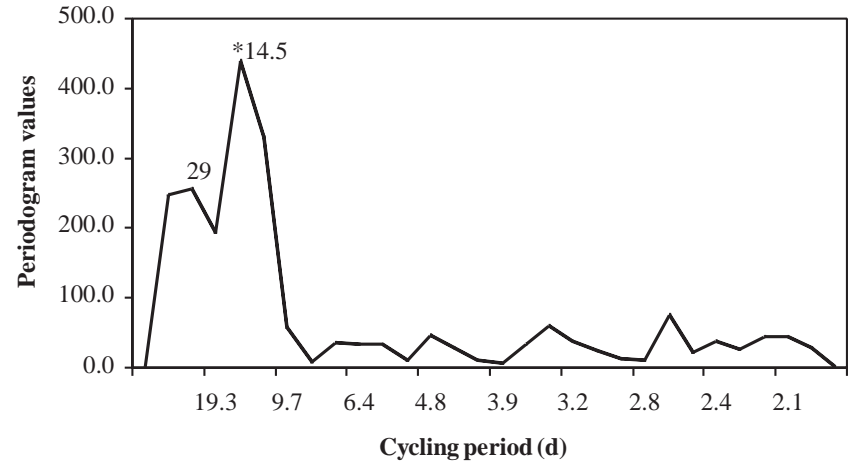

Fig. 5. Paralabrax clathratus. Cycling patterns in daily settlement at Ripper's Reef in 1998 based on spectral analysis. Highest and widest peaks were interpreted as the dominant cycling patterns or periodicities (Chatfield 1980). Spectral analysis revealed a dominant $* 14.5$ d cycling period along with a strong cycling period of $29 \mathrm{~d}$ 
Table 2. Paralabrax clathratus. Nonparametric Spearman Rank Correlation (R) for daily settlement at Ripper's Reef in 1998 (58 sampling days) and the four physical parameters measured in the field. An adjusted significance level of 0.0125 was used to limit the overall experimental error rate

\begin{tabular}{|lrc|}
\hline Physical parameter & $\mathrm{R}$ & $\mathrm{p}$ \\
\hline Tidal amplitude $(\mathrm{m})$ & 0.367 & 0.0045 \\
Detrended surface water temp. $\left({ }^{\circ} \mathrm{C}\right)$ & -0.372 & 0.0040 \\
N-S wind components $\left(\mathrm{m} \mathrm{s}^{-1}\right)$ & 0.453 & 0.0004 \\
E-W current components $\left(\mathrm{cm} \mathrm{s}^{-1}\right)$ & 0.294 & 0.0343 \\
\hline
\end{tabular}

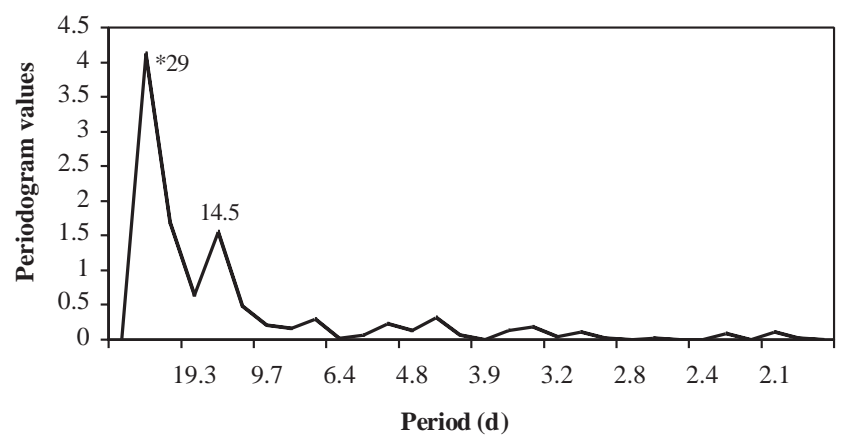

Fig. 6. Cycling patterns of detrended surface temperatures at Ripper's Reef in 1998 based on spectral analysis. A dominant *29 d cycling period, along with a strong $14.5 \mathrm{~d}$ cycling period, were apparent. The highest peak coincides with the length of the sampling period (58 d) and is an artifact of the analysis

the strength of onshore winds (i.e. the north-south wind components; $R=0.45, \mathrm{n}=58, \mathrm{p}=0.0004)$. The east-west or along-shore current component did not show a significant correlation with settlement of kelp bass based on the adjusted $\mathrm{p}<0.0125$ (Table 2).

\section{Presence of internal tidal bores}

To determine whether settlement of kelp bass was correlated with physical features of surface slicks or internal bores, the results from the rank correlations as well as evidence from the temperature readings were examined (Fig. 7). Around each new and full moon, $8 \mathrm{~d}$ sections of $10 \mathrm{~min}$ readings were expanded for better resolution (Fig. 8).

Temperature readings around the first new moon revealed a distinct drop in surface temperature beginning on July 22 (Fig. 8) and semi-diurnal fluctuations in bottom temperature from July 21 to 23 . Temperature readings around the second new moon did not show distinct drops in surface temperature; however, delayed semi-diurnal drops in bottom temperature consistent with tidal changes were evident from August 23 to 25 (Fig. 8).

Temperature readings near the first full moon revealed a distinct declines in surface temperature from August 4 to 13 and semi-diurnal drops in bottom temperature from August 6 to 10 (Fig. 8). Temperature readings near the second full moon indicated a drop in surface temperature beginning on September 4 and semi-diurnal fluctuations in bottom temperature from September 3 to 8 (Fig. 8). Therefore, we conclude that internal bores, as inferred from these abrupt drops in surface temperature and semi-diurnal fluctuations in bottom temperature consistent with tidal regime, were present at both new moons and both full moons. Bore formation did appear to be delayed with respect to moon phase during the second new moon of the study. Very few kelp bass settled during the second new moon.

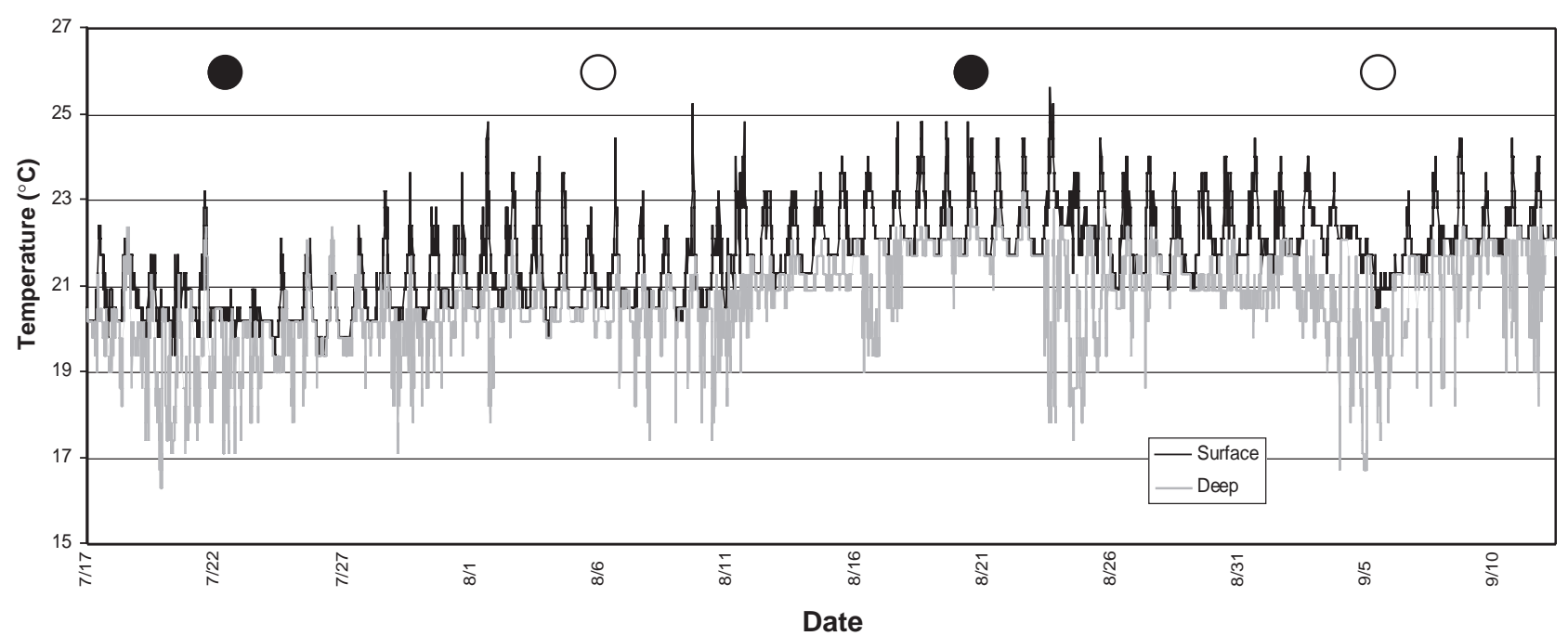

Fig. 7. Temperature (10 min readings) throughout the sampling period at Ripper's Reef. The presence of internal bores is inferred by the semi-diurnal fluctuations in surface and bottom temperatures. $\bullet=$ new moon, $\mathrm{O}=$ full moon 

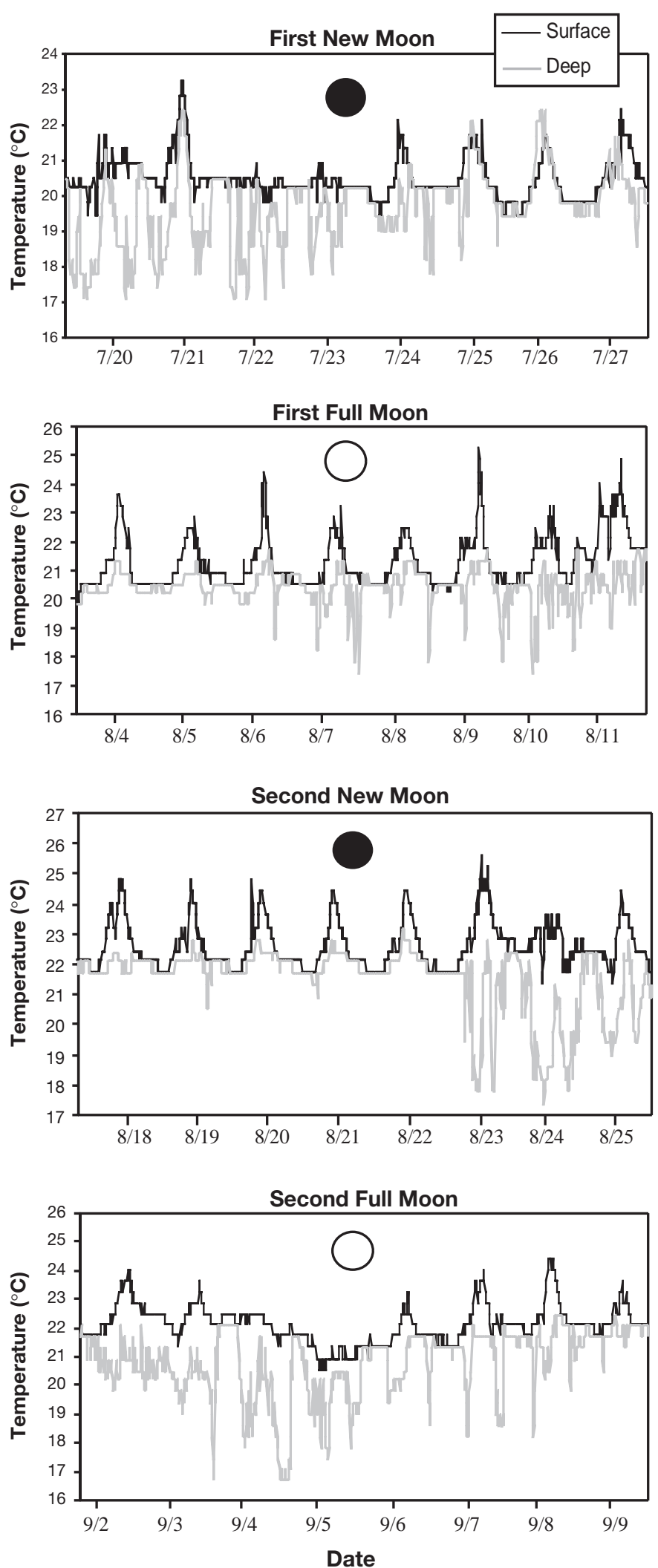

Fig. 8. Temperature (10 min readings) near the new and full moons for the sampling period at Ripper's Reef. The presence of internal bores is inferred by lowered surface temperatures and semi-diurnal fluctuations in bottom temperature

\section{Age-length relationship}

A total of 94 settlers were aged, with a mean age of $27.88 \pm 3.21 \mathrm{~d}$. An age-length relationship was determined for all aged and measured kelp bass $(n=89)$, which then was applied to all measured settlers to estimate spawning patterns. The age-length relationship was represented by the significant $\left(\mathrm{r}^{2}=0.69, \mathrm{df}=88\right.$, $\mathrm{p}<0.01$ ) linear regression $y=2.81 x+1.17$ (Fig. 9). The $\mathrm{SD}$ about the regression line was $\pm 1.71 \mathrm{~d}$. The average daily growth predicted by the model for fish in this size range ( 7.5 to $14.5 \mathrm{~mm} \mathrm{SL}$ ) was $0.36 \mathrm{~mm} \mathrm{~d}^{-1}$, lower than the daily growth rate of $0.59 \mathrm{~mm} \mathrm{~d}^{-1}$ for fish in the size range of 8.6 to $39.5 \mathrm{~mm}$ SL estimated by Cordes \& Allen (1997). This regression was used to predict the ages of remaining settlers that were not aged. Individual spawn dates were back-calculated from the 187 age estimates (Fig. 10).

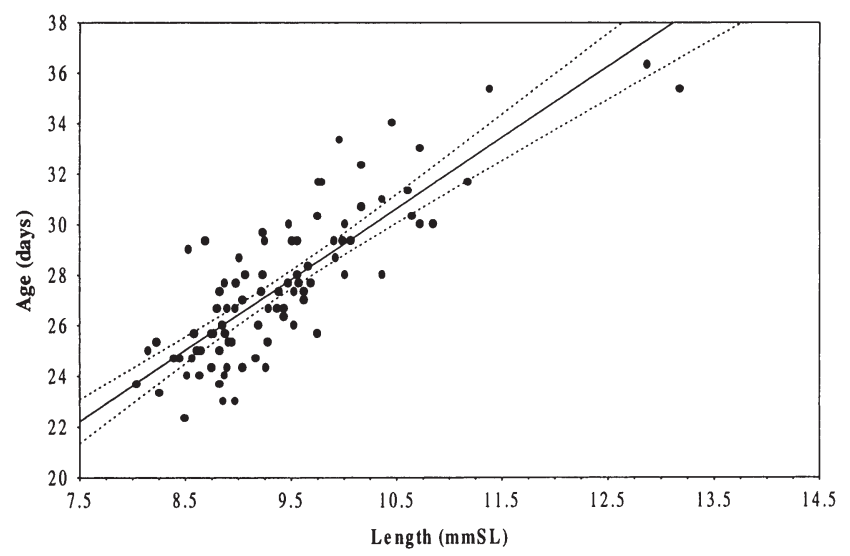

Fig. 9. Paralabrax clathratus. Age-length regression for daily settlers $(n=89)$ at Ripper's Reef, $1998 ; y=1.17+2.81 x\left(\mathrm{R}^{2}=\right.$ $0.69, \mathrm{p}<0.01), \mathrm{SD} \pm 1.71 \mathrm{~d}$. Dotted lines represent $95 \%$ confidence limits

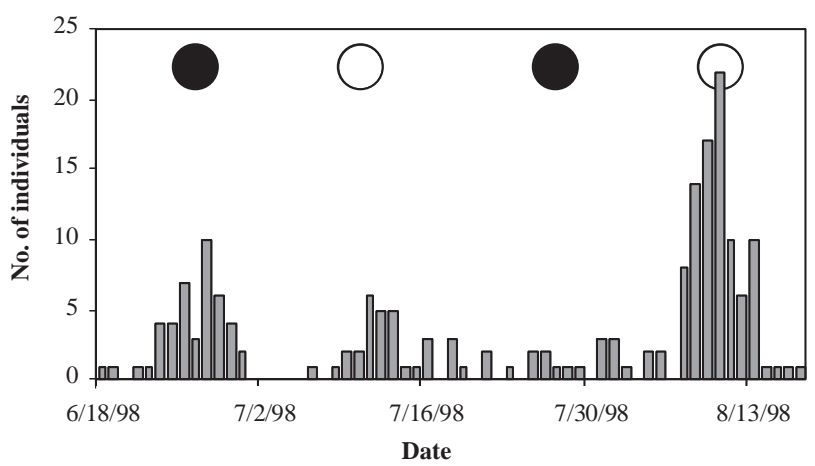

Fig. 10. Paralabrax clathratus. Estimated back-calculated spawn dates using the age-length linear regression for 1998 settlers ( $\mathrm{n}=187$ ) at Ripper's Reef. $\bullet=$ new moon, $\mathrm{O}=$ full moon 


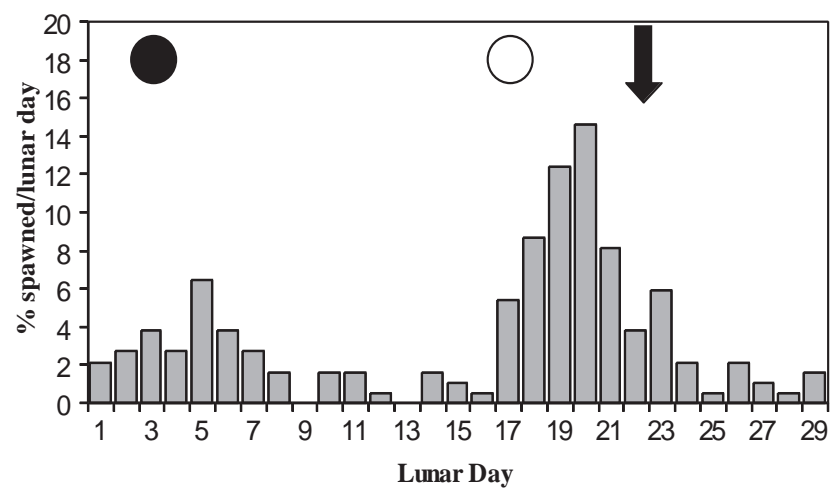

Fig. 11. Paralabrax clathratus. Estimated lunar patterns of spawning at Ripper's Reef in 1998 based on Rayleigh statistics and back-calculated spawn dates $(\mathrm{n}=187)$. The downward black arrow indicates the date of peak spawning (Day 20.5, see Table 1)

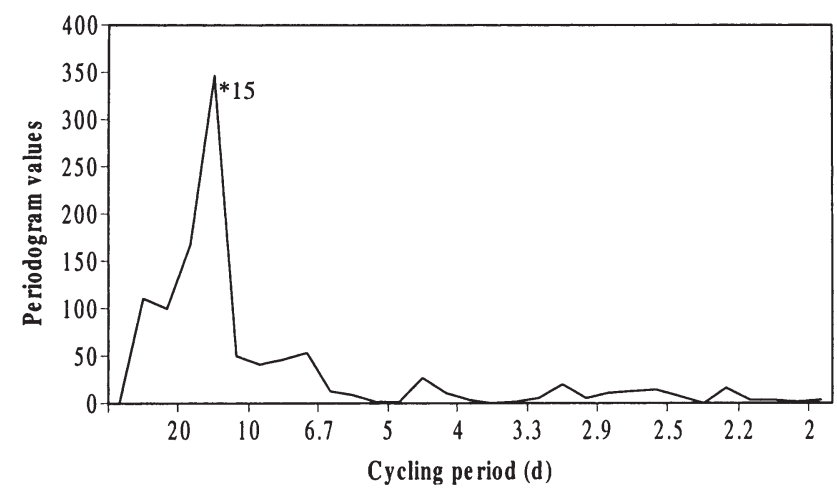

Fig. 12. Paralabrax Clathratus. Estimated cycling patterns in daily spawning at Ripper's Reef in 1998 based on spectral analysis. Spectral analysis revealed a dominant $* 15$ d cycling period in kelp bass spawning. See Fig. 10 for details

\section{Spawning cycle patterns}

A highly significant Rayleigh $Z$-statistic $(Z=95.0$, $\mathrm{df}=186, \mathrm{p}<0.001$ ) for back-calculated spawn dates of successful settlers indicated that spawning was not uniformly distributed around a lunar cycle. The mean vector of the circular distribution (Fig. 11) indicated a date of peak spawning at D 20.5 of the lunar cycle, approximately $5.5 \pm 3.5 \mathrm{~d}$ days after the full moon. Spectral analysis revealed a dominant cycling period of $15 \mathrm{~d}$ (Fig. 12) suggesting that kelp bass spawning may have a lunar periodicity around the new and full moons, with the peak in spawning occurring around the full moon.

\section{Settlement length and age per tidal phase}

A significant difference was found among the 4 moon phases for both length at settlement (1-way
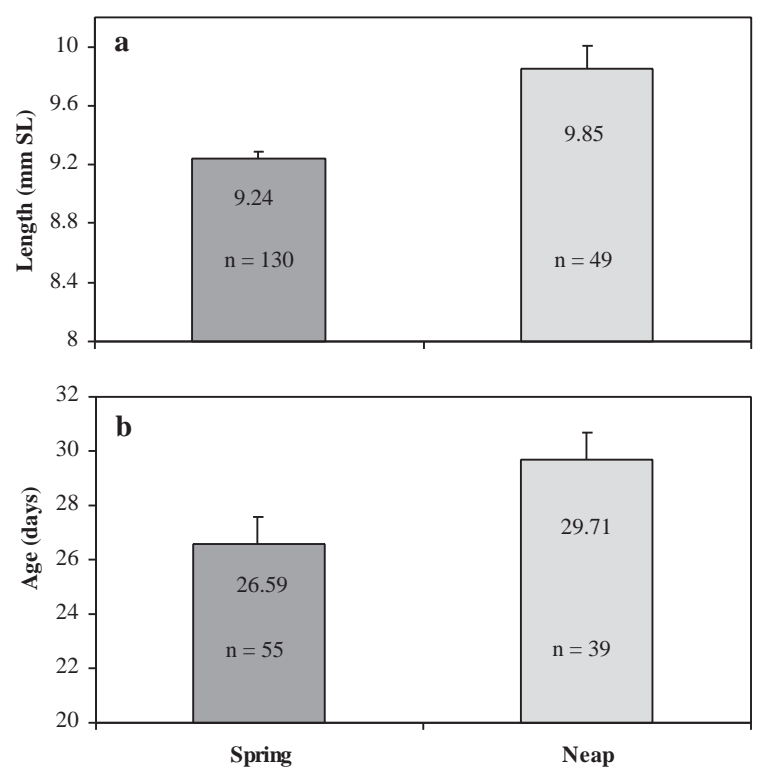

Fig. 13. Paralabrax clathratus. Length (a) and age (b) at settlement per tidal cycle at Ripper's Reef in 1998 (mean \pm SE). Length and age per tidal cycle were significantly different (Table 3)

ANOVA, $\left.F_{(3,176)}=9.81, \mathrm{p}<0.001\right)$ and age at settlement $\left(F_{(3,90)}=9.45, \mathrm{p}<0.001\right)$ of kelp bass. Post hoc comparisons showed no significant difference between new and full moons ( $p=0.41, p=0.98)$ and between first quarter and third quarter moons for both length at settlement $(p=0.71)$ and age at settlement $(p=0.91)$. Length at settlement was significantly different between kelp bass that settled during spring tides and those that settled during neap tides (Fig. 13, Table 3). Kelp bass that settled during the new and full moons were also significantly smaller and less variable (9.24 $\mathrm{mm} \mathrm{SL} \pm 0.54 \mathrm{SD}, \mathrm{n}=130$ ), than those that settled during the quarter moons (9.85 mm SL $\pm 1.11 \mathrm{SD}, \mathrm{n}=49$ ).

Age at settlement was also significantly different between kelp bass that settled during spring tides as opposed to neap tides. Kelp bass that settled during the new and full moons were also significantly younger and less variable $(26.59 \mathrm{~d} \pm 2.26 \mathrm{SD}, \mathrm{n}=55)$ than those that settled during the quarter moons $(29.71 \mathrm{~d} \pm 3.47 \mathrm{SD}$, $\mathrm{n}=39$; Fig. 13).

Table 3. Paralabrax clathratus. One-way ANOVA for standard length (SL) and age per tidal phase at Ripper's Reef in 1998

\begin{tabular}{|lcccccc|}
\hline & $\begin{array}{c}\text { df } \\
\text { effect }\end{array}$ & $\begin{array}{c}\text { MS } \\
\text { error }\end{array}$ & $\begin{array}{c}\text { df } \\
\text { error }\end{array}$ & $\begin{array}{c}\text { MS } \\
\text { error }\end{array}$ & $F$ & $p$ \\
\hline SL & 1 & 13.2 & 178 & 0.55 & 23.95 & 0.000002 \\
Age & 1 & 222.3 & 92 & 7.98 & 27.88 & 0.000001 \\
\hline
\end{tabular}




\section{DISCUSSION}

The results from the 1997 pilot study in Big Fisherman Cove indicate that the majority of kelp bass settle at mid depths and are likely to be transported inshore at this depth. Carr (1991) found a similar pattern of vertical distribution of kelp bass recruits along Macrocystis plants. Larvae should occur near the surface for effective onshore transport in surface slicks or near the bottom for effective onshore transport as a result of internal tidal bores (Le Fèvre \& Bourget 1992). Our results do not support the surface slick transport hypothesis for kelp bass because most settlers were not found in shallow depth collectors.

Daily settlement of kelp bass at Ripper's Reef in 1998 strongly suggests semi-lunar periodicity at or near new and full moons, which is a pattern shared with another temperate species of sea bass, the gag Mycteroperca microlepis from the mid-Atlantic Bight (Keener et al. 1988). More commonly, a unimodal cycle is observed around either the full or the new moon. Settlement centered around the new moon has been observed for several species of coral reef fishes on Panamanian (Robertson 1992) and Caribbean reefs (Sponaugle \& Cowen 1997). Lunar patterns of settlement may also be influenced not only by the relative brightness at night, but also by tidal amplitude (Sponaugle \& Cowen 1996). For example, Robertson (1992) found that settlement of an acanthurid peaked between the new and full moons during two-thirds of the months sampled, then shifted to a semi-lunar pattern of settlement for the remaining months, suggesting that tides may be the dominant factor influencing settlement. Because lunar periodicity in spawning may represent a strategy to enhance offshore flushing of eggs and larvae (Johannes 1978), timing of settlement might reasonably be related to the size or the dial timing of the tides rather than to lunar brightness (Williams et al. 1983, Sponaugle \& Cowen 1997).

Because settlement of kelp bass was observed at both new and full moons, the influence of tidal regimes and/or other oceanographic events is likely. The high positive correlation between settlement of kelp bass and tidal amplitude suggests that peaks in settlement occur at or near tides with high amplitudes (spring tides) and that internal bores are a likely means of onshore transport. Peak catches of the inertial crab Pachygrapsus crassipes (Shanks 1983) and intertidal barnacle larvae Chthamalus spp. (Shanks \& Wright 1987) occur several days before the spring tide, when internal waves and surface slicks were present. During spring tides, internal waves may break in shallow water, generating turbulent internal bores which disturb the water column (Le Fèvre \& Bourget 1992, Leichter et al. 1996). Hence, if kelp bass are utilizing surface slicks as a means of onshore transport, peaks in settlement would likely occur during tides of small amplitude or during neap tides.

The high negative correlation between settlement of kelp bass and surface water temperature indicates that the mechanism which causes drops in surface temperature is also transporting larvae onshore. The results presented here are in agreement with those found between barnacle settlement and surface water temperature anomaly, in which Pineda (1991) suggested internal tidal bores as the likely means of onshore transport. Semi-diurnal internal tides may also play an important role in macronutrient enrichment by transporting cold, nutrient-rich waters to the surface (Zimmerman \& Kremer 1984). Such periodic upward vertical movements of the thermocline are strongest during the summer months on the leeward side of Santa Catalina Island (Zimmerman \& Kremer 1984), and typically recur every $2 \mathrm{wk}$ with the spring tides (Newberger 1982). Our results for surface temperatures recorded at Ripper's Reef are consistent with these previous studies and indicate a predictable pattern of $2 \mathrm{wk}$ and 1 mo declines in sea surface temperature.

Behavioral or passive synchronization to the lunar and/or tidal cycles may result in regular, predictable peaks in settlement, while less predictable large-scale events may also greatly influence the nearshore transport of larvae (Sponaugle \& Cowen 1996). Kingsford \& Finn (1997) found peak abundances for many groups of competent fish larvae at One Tree Island, Great Barrier Reef, just after new and full moons, but also in association with strong onshore winds, which were stochastic events. In addition, 4 of 6 taxa examined by Thorrold et al. (1994) showed significant relationships between larval supply and onshore winds. Thus, variability in wind direction and intensity may be an important factor in determining levels of larval replenishment (Milicich 1994). Wind stress may influence the distribution of larvae by creating or disrupting nearshore currents and areas of larval retention (Milicich 1994, Sponaugle \& Cowen 1996).

Conversely, offshore winds may lead to offshore surface transport while facilitating upwelling and the production of planktonic food. Because wind-induced upwelling typically occurs on an average of only twice during a summer in the Southern California Bight (Dorman \& Palmer 1981), tidally driven upwelling or internal tidal bores serve to better explain the drops in surface temperature recorded in this study. The high positive correlation between settlement of kelp bass and wind direction suggests that settlement of kelp bass was influenced to some extent by the presence of high onshore winds. Wind velocity was typically greater than $10 \mathrm{~m} \mathrm{~s}^{-1}$ during each settlement event of kelp bass, which is in direct conflict with the surface 
slick hypothesis. Winds stronger than 6 to $7 \mathrm{~m} \mathrm{~s}^{-1}$ disrupt the nearshore pattern of surface slicks and internal waves (Norris 1963, Shanks \& Wright 1987, Kingsford 1990).

While no significant correlation was found between settlement of kelp bass and along shore currents, we note that an adjusted significance level was used and that the current meter was in close proximity to the bottom. Zimmerman \& Kremer (1984) reported that the along shore currents on the leeward side of Santa Catalina Island were related to the stage of the tide, running toward the east end of the island on falling tides and toward the west end on rising tides. In southern California, onshore flow is generated by either winds or tides (Winant \& Bratkovich 1981) and is high during the summer months when spawning of kelp bass occurs.

If larvae are capable of remaining planktonic for extended periods, then short-term fluctuations in oceanographic conditions and/or food supply may have less of an effect on population dynamics and future stock size than might otherwise be expected (Victor 1986, Francis 1994, Sponaugle \& Cowen 1994). Greater flexibility in duration may enable closer coupling of settlement to a particular lunar phase, assuming that synchronous settlement is advantageous and entails less risk than settling during a sub-optimal lunar phase (Sponaugle \& Cowen 1994). In addition, such flexibility in larval duration may lead to the dispersal or colonization of wide biogeographic regions (Sponaugle \& Cowen 1994). Victor (1986) reported larval durations for blue-headed wrasse Thalassoma bifasciatum to range from 38 to $78 \mathrm{~d}$ and in an earlier study to range from 40 to $72 \mathrm{~d}$ (Victor 1982). Kingsford \& Milicich (1987) found considerable variation (22 to $66 \mathrm{~d}$ ) in larval duration of a monacanthid fish and suggested that linear oceanographic features may contribute to this pattern. Such differences in larval duration may be due to the timing of association with local oceanographic features. Cordes \& Allen (1997) found evidence for delayed settlement in 4 recently settled kelp bass, suggesting that they may have undergone a slow-growth phase that delayed their time of settlement.

In the absence of onshore transport, planktonic larvae may spend more time in the pelagic environment and a greater age or size range may be expected (Kingsford \& Choat 1986, Kingsford \& Milicich 1987). The small range of larval durations (22 to $36 \mathrm{~d}$ ) reported here suggests that kelp bass possess limited physiological flexibility in larval duration $(28 \pm 3 \mathrm{~d}$ ). Kelp bass which settled around the spring tides were significantly smaller and younger than those which settled around the neap tides, which suggests that spawning of, at least, the successful settlers occurs around the spring tide and oceanographic features may be facilitating onshore transport and shortening larval durations during these times. However, further, detailed study of the reproductive behavior of adult kelp bass will be required before we may conclude that all kelp bass spawning is synchronized to the lunar and tidal cycles.

Spawning events and/or planktonic processes may act to determine the early stages of settlement events, whereas at smaller temporal and spatial scales, habitat selection and early mortality may act to decouple this relationship (Milicich et al. 1992). For example, patterns of reef fish recruitment to St. Croix, US Virgin Islands, appear to be influenced by physical oceanographic processes rather than by habitat selection. However, once delivered to sites, settlers may be distributed based on habitat selection (Caselle \& Warner 1996). Previous studies have indicated that densities of recently settled kelp bass may be a consequence of the presence and dynamics of Macrocystis forests (Carr 1989, 1994, DeMartini \& Roberts 1990), such that both the quantity and quality of the recruitment habitat, rather than larval supply, may be the limiting factor (Carr 1994). In addition, some fish larvae are very active swimmers (Stobutzi \& Bellwood 1994) and have the capability to preferentially settle in particular habitats (Booth 1992, Levin 1993, Milicich \& Doherty 1994, Schmitt \& Holbrook 1996). Therefore, knowledge of the locomotory and sensory abilities of pre-settlement kelp bass will be required to fully understand their recruitment.

This study presents evidence for onshore transport of competent kelp bass larvae by internal tidal bores on the leeward side of Santa Catalina Island. The majority of kelp bass settled to a mid depth zone during high amplitude spring tides, periods of high winds and periods when the surface water temperature declined dramatically. Inspection of the temperature record revealed compelling evidence for the presence of internal bores in the form of abrupt declines in sea temperature at both new and full moons. Lack of settlement during the second new moon in summer 1998 further strengthens the case for the tidal bore transport of settling kelp bass. Although the sparse settlement could be attributed to low larval supply, we believe that it was more likely to have been caused by the observed delay in internal tidal bore formation during that period.

Acknowledgements. This research was supported by a graduate internship from the USC Wrigley Institute for Environmental Studies on Santa Catalina Island, funding from the Nearshore Marine Fish Research Program at California State University Northridge and a grant from the Student Projects Committee at California State University Northridge. Special thanks go to S. Anderson, D. Conlin, P. Dixon, K. Flanagan, S. Grunwald, J. Hooykaas, M. Hughes, J. Malone, H. Stewart, K. 
Wisenbaker and C. Yonker for their diving assistance. We thank the staff at the Wrigley Institute for their assistance and encouragement. Additional thanks go to S. Anderson, C. Blanchette, A. Brooks, J. Caselle, T. Dickey, P. Edmunds, F. Findlay, S. Gaines, J. Malone, J. Pineda, A. Shanks, M. Steele, L. Washburn and P. Wilson for their advice and comments. T. Anderson, R. Carpenter, M. Carr and M. Franklin provided helpful comments on various drafts of this manuscript.

\section{LITERATURE CITED}

Batschelet E (1981) Circular statistics in biology. Academic Press, London

Booth DJ (1992) Larval settlement patterns and preferences by domino damselfish Dascyllus albisella Gill. J Exp Mar Biol Ecol 155:85-104

Cairns JL (1968) Thermocline strength fluctuations in coastal waters. J Geophys Res 73:2591-2595

Caley JM, Carr MH, Hixon MA, Hughes TP, Jones GP, Menge BA (1996) Recruitment and the local dynamics of open populations. Annu Rev Ecol Syst 27:477-500

Campana SE (1984) Interactive effects of age and environmental modifiers on the production of daily growth increments in otoliths of plainfin midshipman, Porichthys notatus. Fish Bull 82:165-177

Carr MH (1989) Effects of macroalgal assemblages on the recruitment of temperate zone reef fishes. J Exp Mar Biol Ecol 126:59-76

Carr MH (1991) Patterns, mechanisms, and consequences of recruitment of a temperate marine reef fish. $\mathrm{PhD}$ thesis, University of California, Santa Barbara

Carr MH (1994) Effects of macroalgal dynamics on recruitment of a temperate reef fish. Ecology 75:1320-1333

Caselle JE, Warner RR (1996) Variability in recruitment of coral reef fishes: The importance of habitat and two spatial scales. Ecology 77:2488-2504

Chatfield C (1980) The analysis of time series: An introduction, 2nd edn. Chapman \& Hall, London

Collyer RD, Young PH (1953) Progress report on a study of the kelp bass, Paralabrax clathratus. Calif Dep Fish Game Fish Bull 39:191-208

Cordes JF, Allen LG (1997) Estimates of age, growth, and settlement from otoliths of young-of-the-year kelp bass (Paralabrax clathratus). Bull South Calif Acad Sci 96:43-60

DeMartini EE, Roberts DA (1990) Effects of giant kelp (Macrocystis) on the density and abundance of fishes in a cobblebottom kelp forest. Bull Mar Sci 46:287-300

Dorman CE, Palmer DA (1981) Southern California summer upwelling. Coastal upwelling, Vol 1. American Geophysicist Union, Washington, DC

Druce BE, Kingsford MJ (1995) An experimental investigation on the fishes associated with drifting objects in coastal waters of temperate Australia. Bull Mar Sci 57:378-392

Francis MP (1994) Duration of larval and spawning periods in Pagrus auratus (Sparidae) determined from otolith daily increments. Environ Biol Fishes 39:137-152

Hutchins JB, Pearce AF (1994) Influence of the Leeuwin current on recruitment of tropical reef fishes at Rottnest Island, Western Australia. Bull Mar Sci 54:245-255

Jensen RE (1990) The aging, validation, and back-calculation of the date of birth and settlement date of young-of-theyear California halibut (Paralichthys californicus) into Alamitos Bay, California using a new technique for the grinding of sagittal otoliths. MS thesis, California State University, Northridge
Johannes RE (1978) Reproductive strategies of coastal marine fishes in the tropics. Environ Biol Fishes 3:65-84

Keener P, Johnson GD, Stender BW, Brothers EB, Beatty HR (1988) Ingress of postlarval gag, Mycteroperca microlepis (Pisces: Serranidae), through a South Carolina barrier island inlet. Bull Mar Sci 42:376-396

Kenyon RA, Haywood MDE, Heales DS, Loneragan NR, Pendrey RC, Vance DJ (1999) Abundance of fish and crustacean postlarvae on portable artificial seagrass units: Daily sampling provides quantitative estimates of the settlement of new recruits. J Exp Mar Biol Ecol 232:197-216

Kingsford MJ (1990) Linear oceanographic features: a focus for research on recruitment processes. Aust J Ecol 15:391-401

Kingsford MJ, Choat JH (1986) Influence of surface slicks on the distribution and onshore movements of small fish. Mar Biol 91:161-171

Kingsford M, Finn M (1997) The influence of phase of moon and physical processes on the input of presettlement fishes to coral reefs. J Fish Biol 51:176-205

Kingsford MJ, Milicich MJ (1987) The presettlement phase of Parika scaber (Pisces: Monacanthidae): a temperate reef fish. Mar Ecol Prog Ser 36:65-79

Lavenberg RJ, McGowen GE, Jahn AE, Petersen JH, Sciarrotta TC (1986) Abundance of southern California nearshore ichthyoplankton: 1978-1984. CalCOFI Rep 27:53-64

Le Fèvre JL, Bourget E (1992) Hydrodynamics and behaviour: Transport processes in marine invertebrate larvae. TREE $7: 288-289$

Leichter JJ, Wing SR, Miller SL, Denny MW (1996) Pulsed delivery of subthermocline water to Conch Reef (Florida Keys) by internal tidal bores. Limnol Oceanogr 41:1490-1501

Levin PS (1993) Habitat structure, conspecific presence and spatial variation in the recruitment of a temperate reef fish. Oecologia 94:176-185

Milicich MJ (1994) Dynamic coupling of reef fish replenishment and oceanographic processes. Mar Ecol Prog Ser 110:135-144

Milicich MJ, Doherty PJ (1994) Larval supply of coral reef fish populations: magnitude and synchrony of replenishment to Lizard Island, Great Barrier Reef. Mar Ecol Prog Ser 110:121-134

Milicich MJ, Meekan MG, Doherty PJ (1992) Larval supply: a good predictor of recruitment of three species of reef fish (Pomacentridae). Mar Ecol Prog Ser 86:153-166

Newberger P (1982) Physical oceanography and meteorology of the California outer continental shelf. US Department of the Interior, Los Angeles POCS Tech Pap 82(2):1-308

Norris KS (1963) The functions of temperature in the ecology of the percoid fish Girella nigricans (Ayres). Ecol Monogr 33:23-62

Oda DL, Lavenberg RJ, Rounds JM (1993) Reproductive biology of three California species of Paralabrax (Pisces: Serranidae). CalCOFI Rep 34:122-132

Pineda J (1991) Predictable upwelling and the shoreward transport of planktonic larvae by internal tidal bores. Science 253:548-551

Pineda J (1994) Internal tidal bores in the nearshore: warmwater fronts, seaward gravity currents and the onshore transport of neustonic larvae. J Mar Res 52:427-458

Pineda J (1995) An internal tidal bore regime at nearshore stations along western USA: predictable upwelling within the lunar cycle. Cont Shelf Res 15:1023-1041

Quast JC (1968) Observations on the food and biology of the kelp bass, Paralabrax clathratus, with notes on its sportfishery at San Diego, California. Calif Dep Fish Game Fish Bull 139:81-108

Robertson DR (1992) Patterns of lunar settlement and early 
recruitment in Caribbean reef fishes at Panama. Mar Biol 114:527-537

Sale PF (1991) Reef fish communities: Open nonequilibrial systems. In: Sale PF (ed) The ecology of fishes on coral reefs. Academic Press, New York, p 564-598

Schmitt RJ, Holbrook SJ (1996) Local-scale patterns of larval settlement in a planktivorous damselfish - do they predict recruitment? Mar Freshw Res 47:449-463

Shanks AL (1983) Surface slicks associated with tidally forced internal waves may transport pelagic larvae of benthic invertebrates and fishes shoreward. Mar Ecol Prog Ser 13: $311-315$

Shanks AL (1985) Behavioral basis of internal-wave-induced shoreward transport of megalopae of the crab Pachygrapsus crassipes. Mar Ecol Prog Ser 24:289-295

Shanks AL (1988) Further support for the hypothesis that internal waves can cause shoreward transport of larval invertebrates and fish. Fish Bull 86:703-714

Shanks AL, Wright WG (1987) Internal-wave-mediated shoreward transport of cyprids, megalopae, and gammarids and correlated long shore differences in the settling rate of intertidal barnacles. J Exp Mar Biol Ecol 114:1-13

Shenker JM, Elizabeth DM, Wishinski E, Pearl A, Thorrold SR, Smith N (1993) Onshore transport of settlement-stage Nassau grouper, Epinephelus striatus and other fishes in Exuma Sound, Bahamas. Mar Ecol Prog Ser 98:31-43

Sokal RR, Rohlf FJ (1995) Biometry. Freeman, New York

Sponaugle S, Cowen RK (1994) Larval durations and recruitment patterns of two Caribbean gobies (Gobiidae): Contrasting early life histories in demersal spawners. Mar Biol 120:133-143

Sponaugle S, Cowen RK (1996) Nearshore patterns of coral reef fish larval supply to Barbados, West Indies. Mar Ecol Prog Ser 133:13-28

Sponaugle S, Cowen RK (1997) Early life history traits and recruitment patterns of Caribbean wrasses (Labridae). Ecol Monogr 67:177-202

Stobutzi IC, Bellwood DR (1994) An analysis of sustained swimming abilities of pre- and postsettlement coral reef fishes. J Exp Mar Biol Ecol 175:275-286

Editorial responsibility: Richard Haedrich (Contributing Editor), St. John's, Newfoundland, Canada
Talbot FH, Russell BC, Anderson GRV (1978) Coral reef fish communities: unstable, high-diversity systems? Ecol Monogr 48:425-440

Thorrold SR, Shenker JM, Maddox ED, Mojica R, Wishinski E (1994) Larval supply of shore fishes to nursery habitats around Lee Stocking Island, Bahamas II: lunar and oceanographic influences. Mar Biol 118:567-578

Vargas CA, Valenzuela GS, Núñez SP, Arcos DF (1997) Role of oceanographic and topographic factors in the retention of hake (Merluccius gayi gayi Guichenot, 1848) larvae in the upwelling system off central-southern Chile. Arch Fish Mar Res 45:201-222

Victor BC (1982) Daily otolith increments and recruitment in two coral-reef wrasses, Thalassoma bifasciatum and Halichoeres bivittatus. Mar Biol 71:203-208

Victor BC (1986) Delayed metamorphosis with reduced larval growth in a coral reef fish (Thalassoma bifasciatum). Can J Fish Aquat Sci 43:1208-1213

Victor BC (1991) Settlement strategies and biogeography of reef fishes. In: Sale PF (ed) The ecology of fishes on coral reefs. Academic Press, New York, p 231-260

Walker HJ, Watson W, Barnett AM (1987) Seasonal occurrence of larval fishes in the nearshore southern California Bight off San Onofre, California. Estuar Coast Shelf Sci 25: 91-109

Williams DM, Wolanski E, Andrews JC (1983) Daily, monthly and yearly variability in recruitment of a guild of coral reef fishes. Mar Ecol Prog Ser 10:231-237

Winant CD, Bratkovich AW (1981) Temperature and currents on the southern California shelf: a description of the variability. J Phys Oceanogr 11:71-86

Witman JD, Leichter JJ, Genovese SJ, Brooks DA (1993) Pulsed phytoplankton supply to the rocky subtidal zone: influence of internal waves. Proc Natl Acad Sci USA 90: $1686-1690$

Zar JH (1984) Biostatistical analysis. Prentice-Hall, Upper Saddle River, NJ

Zimmerman RC, Kremer JN (1984) Episodic nutrient supply to a kelp forest ecosystem in Southern California. J Mar Res 42:591-604

Submitted: April 21, 2000, Accepted: February 12, 2002 Proofs received from author(s): July 25, 2002 